$\mathrm{Oz}$

Volume 28

Article 9

$1-1-2006$

\title{
Present to Future
}

Larry Bowne

Patrick Rhodes

Follow this and additional works at: https://newprairiepress.org/oz

(c) $($ ) $\Theta \Theta$

This work is licensed under a Creative Commons Attribution-Noncommercial-No Derivative Works 4.0 License.

\section{Recommended Citation}

Bowne, Larry and Rhodes, Patrick (2006) "Present to Future," Oz: Vol. 28. https://doi.org/10.4148/

2378-5853.1434

This Article is brought to you for free and open access by New Prairie Press. It has been accepted for inclusion in Oz by an authorized administrator of New Prairie Press. For more information, please contact cads@k-state.edu. 


\section{Present to Future}

A Conversation

\author{
Larry Bowne and Patrick Rhodes
}

Patrick Rhodes: I'd like to start by laying out some general ideas and an overall thesis. During the late 1700s and late 1800s in Britain and Europe, scientific knowledge launched the industrial revolution, a dry-run at globalization and the global climate of the late twentieth century. People began to investigate how social and political openness can combine with geographical mobility to spawn a renaissance. Openness between scholars, scientists and inventors, along with the free flow of information between them, led to economic growth and cultural transformation. Jeffrey Sachs states in "The End of Poverty":

The beauty of ideas is that they can be used over and over again, without ever being depleted. Economists call ideas non-rival in the sense that one person's use of an idea does not diminish the ability of others to use it as well. This is why we can envision a world in which everybody achieves prosperity.

Larry Bowne: Well, what about those people who don't have access to technological innovation, or whose society is restricted, either socially or politically?

PR: Restriction of information and isolationist thinking breeds poverty, even extreme poverty. The twentiethcentury third world, or those countries who wanted nothing to do with the first-world capitalist economies, or with isolated themselves and closed themselves offfrom global economic progress, free markets, and new technologies. They created high-cost local industries that could not compete internationally and by sheltering themselves from competition, encouraged corruption.

LB: But Patrick, that's sort of grandarc-of-history stuff. What about today? What about student-initiated humanitarian design/build?

PR. I believe that a parallel can be drawn between the last two hundred years of economic progress and our recent global situation, even in terms of the greater architectural community, and humanitarian design specifically. If Great Britain's ability to transform the world so dramatically during the 1800 s can be attributed to a few necessary factors: transmission of ideas, freely developing technology, and geographic freedom, then our world: one in which the twentieth-century first world, through economic explosion, left behind the third world, one billion people, in economic stagnation and extreme poverty, is ripe for a new technological and social revolution, a new renaissance.

\section{LB: How?}

PR: Our tools are the fruits of our economic growth, our intellectual freedom, a luxury in terms of the rest of the world; and the disparity of resources which leads us to believe we have a responsibility to aid those less fortunate. We are guilty, rich, and have the time and freedom to affect change. If there is a discernible movement in architecture today toward humanitarian goals, it is because of the confluence of these factors, and it is only stalled because of the absence of another, necessary part: progressive technology. Architecture has been practiced, for the most part, the same, old way for decades and centuries. These new technologies, new ways to apply ideas and resources have the ability to catapult our profession and catalyze global economic prosperity.

LB: In the fall of 2005, you organized a national conference at the University of Arkansas to bring together people from universities and the humanitarian design community to discuss how both might contribute to the rebuilding of New Orleans. How did you know you wanted to organize a summit?

PR: I organized the Arkansas Summit for one very simple reason: I was tired of being a director of a design/build nonprofit and yet unable to respond quickly, or in any manner really, to natural disasters and other cataclysmic events; I was frustrated.

\section{LB: Frustrated?}

PR: Yes. If you are a relieforganization working in the field of medicine, there are well-organized networks and mechanisms in place to allow practitioners to address critical needs in a timely fashion. The architecture profession has no such mechanism in place. Ifounded Project Locus shortly before the 9/11 disaster and at that time I did not have the capacity to respond in any substantial way to that crisis. Since then, because I have been focused on this type of work, I have followed natural disasters, wartorn countries and refugee conditions, and areas of crisis and need globally, including the 2004 tsunami, the Bam earthquake and the Darfur crisis. I have come to find that these situations exist and occur with great frequency and at extreme human cost. As a designer, as a human, I am compelled to act.

LB: So in a way you were looking for a disaster where your response could make a difference.

PR: At the time that the Hurricane Katrina disaster occurred, I wasn't sure if Project Locus had the capability to react in a critical manner on our own, but I felt that we could do some good if we were allied with similar groups working toward a common goal. Within a week of the event, I had put out a call to action to the architecture community at large, proposing a nation-wide collaborative, and received a wide and positive response. We eventually partnered with Tulane University to host a series of conferences, which resulted in the establishment of a National Design Build Consortium now comprised of a dozen nationally-recognized programs, and several design build projects initiated in New Orleans including a project undertaken by the University of Kansas 

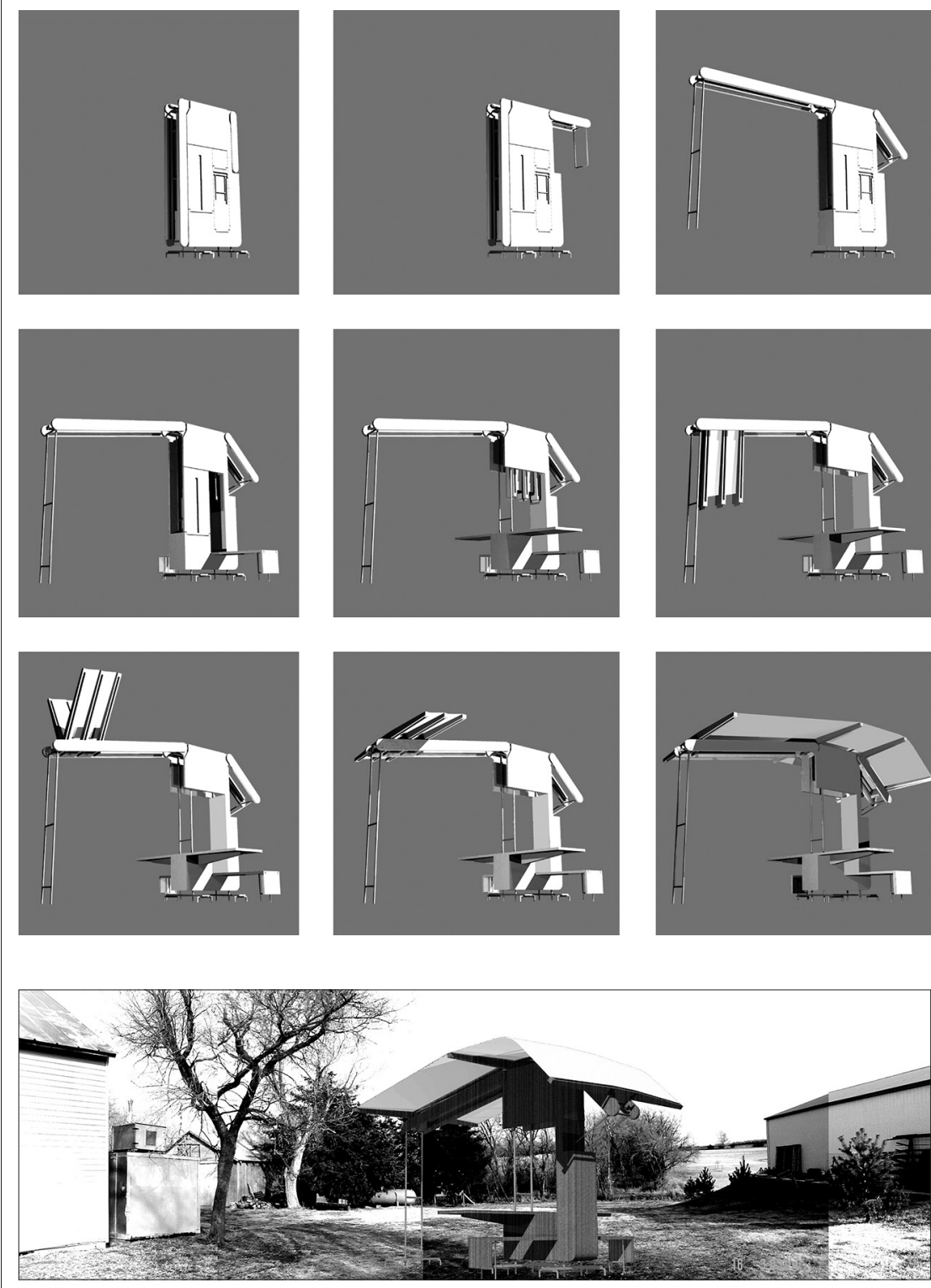

Shelley Prototype Transportable Pavilion-Scott Newland and Peter Todd, B.Arch. 2006

A prefabricated portable pavilion constructed of plywood. It can be utizlized in pratically any site condition, and, when erected, can accomodate up to eight people. begun this spring, and our own which will be completed this summer.

While there were several notable sum mits, conferences, and discussions during the last several months focused on addressing the New Orleans crisis, $I$ feel that no single initiative on its own provided a comprehensive solution but our critical mass as a profession has focused our attention and clarified our direction.

LB: What has happened since?

PR: As a result of these many talks, and the need for collaboration, the SEED (Social Economic and Environmental Design) network was formed, and is the manifestation of my original goal. I attended its second meeting in February at Tulane University, and was very excited to see the biggest and brightest players in community design at the table. The thing that I have been searching for during the past several years may become a reality: a nation wide, organized network, and a web site which serves a "bat-signal" to alert and rally practitioners to respond to dire need. Finally, I suppose I knew I wanted to organize a summit to make those things happen.

LB: But America has an extremely efficient housing industry and we know how to develop real estate in this country. Won't the market address the sort of issues you are describing? Does the work you are doing have to be done by a non-profit? Is profit somehow in the way of doing good?

PR: That's a loaded question, Larry. At the heart of it is the layman's misunderstanding about what a nonprofit really is. "Nonprofit" does not mean that you cannot make a profit. In legal terms it means that no single person associated with the organization can record a profit, or benefit excessively. It's a subtle difference. As long as a nonprofit corporation is organized and operated for a recognized nonprofit, charitable purpose it can make a profit from its activities, but it must apply this profit towards its programs. In fact, the students in my seminar this semester, Architecture for the Underserved, have been tasked with creating a nonprofit organization, which develops an initial program in fulfillment of its mission (designing in areas of need) and ultimately creates a marketable product, which appeals to a wide audience. In conventional nonprofit practice, organizations must constantly seek funding from outside sources for their programs, and in that way do not contribute to the market, but are a drain on it. The focus of my research is to create a nonprofit business model which fulfills needs in the marketplace as well as for underserved populations, and creates a dedicated, sustainable funding source for their continuing work, eliminating the need for additional fund raising. It is $m y$ opinion that this is the direction of the third sector, considering that funding streams in the last decade have 
continued to dry up, and the current trend is collaboration and piggy-back fund raising. Ibelieve that, especially in design-oriented nonprofits, sustainable revenue streams can only be achieved by developing new products through innovative technologies, such as prefabrication and rapid prototyping.

Your question makes me wonder about you. Why are you, a former high-end, $1 \%$ designer interested in Hurricane Katrina summits, design-builds and serving needy populations?

LB: I suppose I would have to note that I am perhaps not so interested in serving needy populations. To be honest, I am not sure I am interested in "serving" any population.

The question I ask myself: what good is our time here? What sort of contribution do we make to the world we find? How do we apply whatever merits or gifts or skills we might have so that we leave this place somehow marginally improved?

The quixotic romantic in me sees the role of the architect as a sort of professional George Bailey in It's $A$ Wonderful Life, contributing to the commonweal in ways that might not ever be explicitly noticed or understood by the folks whose lives are indeed being ameliorated.

PR: How did you come to this conclu-
LB: For seven years I worked in New York, and to work in New York you do a lot of residential work. You encounter people who have stores of capital that simply boggle the mind. I grew up middle class, and I thought everyone was more or less gifted with the same opportunities and possibilities. The myth of the meritocracy is strong in this country, and I accepted it rather uncritically.

As an employee, I worked on a triplex penthouse where the living room alone, in its art and antiques and interior décor, had an assessed value of a half billion dollars. I thought my career was proceeding successfully.

Later, I had my own firm, and my experience with so-called "high-end" clients continued. I worked on a range of projects, one of which became one of those maelstroms of negativity on which Hollywood bases reality television series: a prima donna contractor ignoring his jet-setting twenty-something actor client, the architect having to placate the howling neighbors and the disgruntled legal advisors. It occurred to me that no matter how hard I worked, no matter how good the quality of my design, and no matter how successfully I realized my vision of space and fabrication, the result was the same: no one would ever see it. Sure, my spoiled client and his sybaritic buddies might enjoy the amenities of the place, might get a kick out of the fact that they could pick up the phone in daddy's plane, call the apartment, tell the place they would be home in two hours, and to load The Empire Strikes Back onto the sixty-inch plasma.
But what sort of work is that? Architects train to master a host of technical information, and to synthesize a wide range of disparate disciplines. How could a penthouse apartment
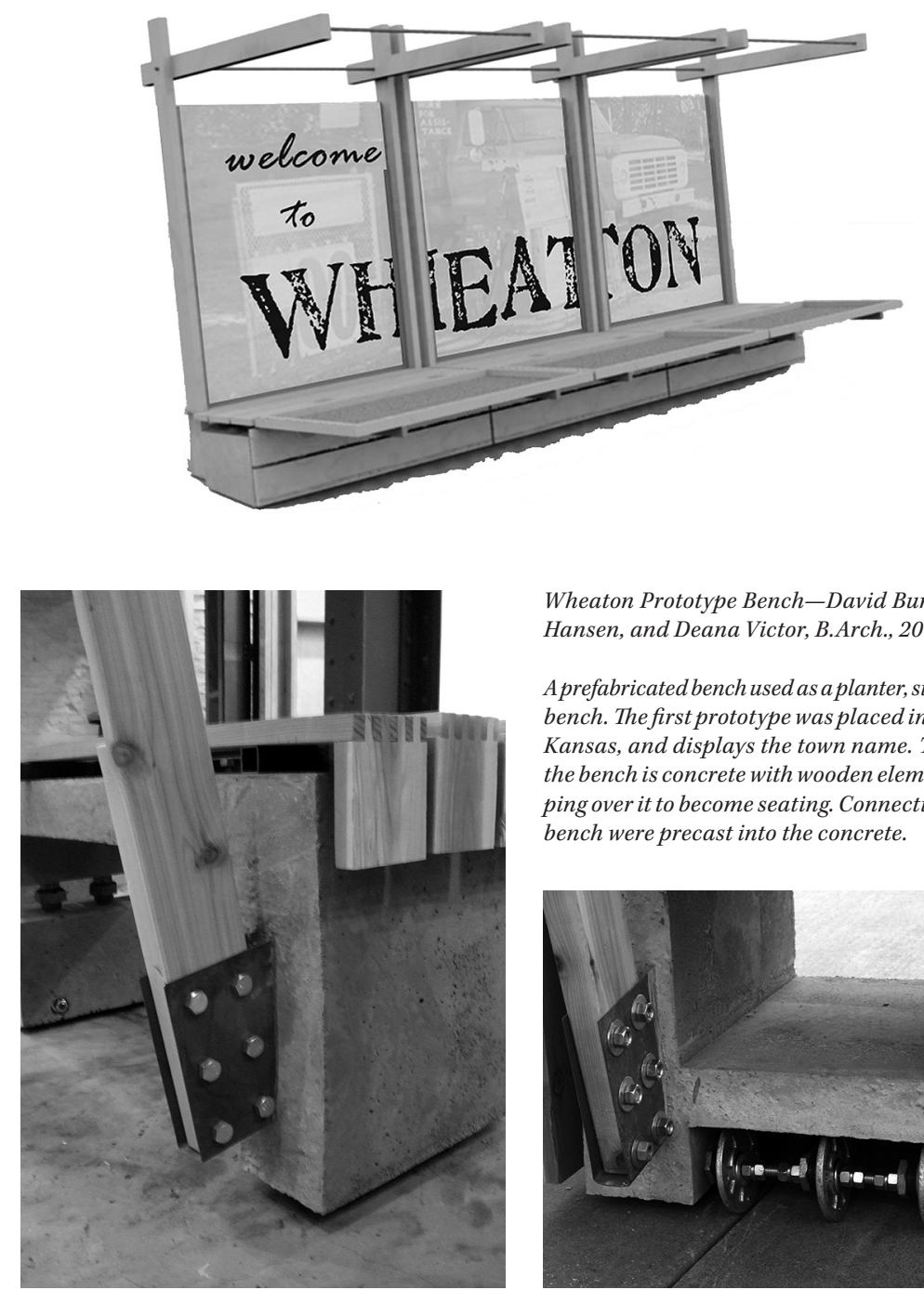

Wheaton Prototype Bench-David Burton, Brent Hansen, and Deana Victor, B.Arch., 2006

A prefabricated bench used as a planter, signage, and bench. The first prototype was placed in Wheaton, Kansas, and displays the town name. The base of the bench is concrete with wooden elements wrapping over it to become seating. Connections for the bench were precast into the concrete.

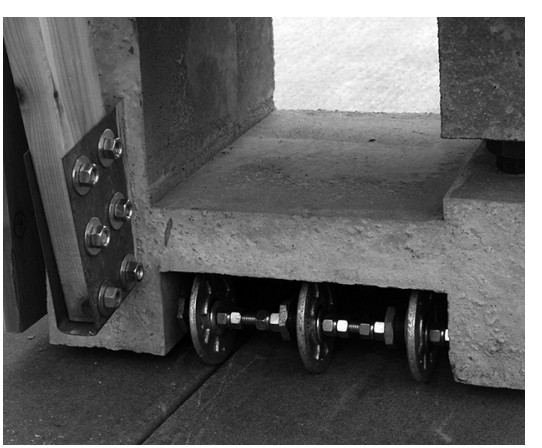



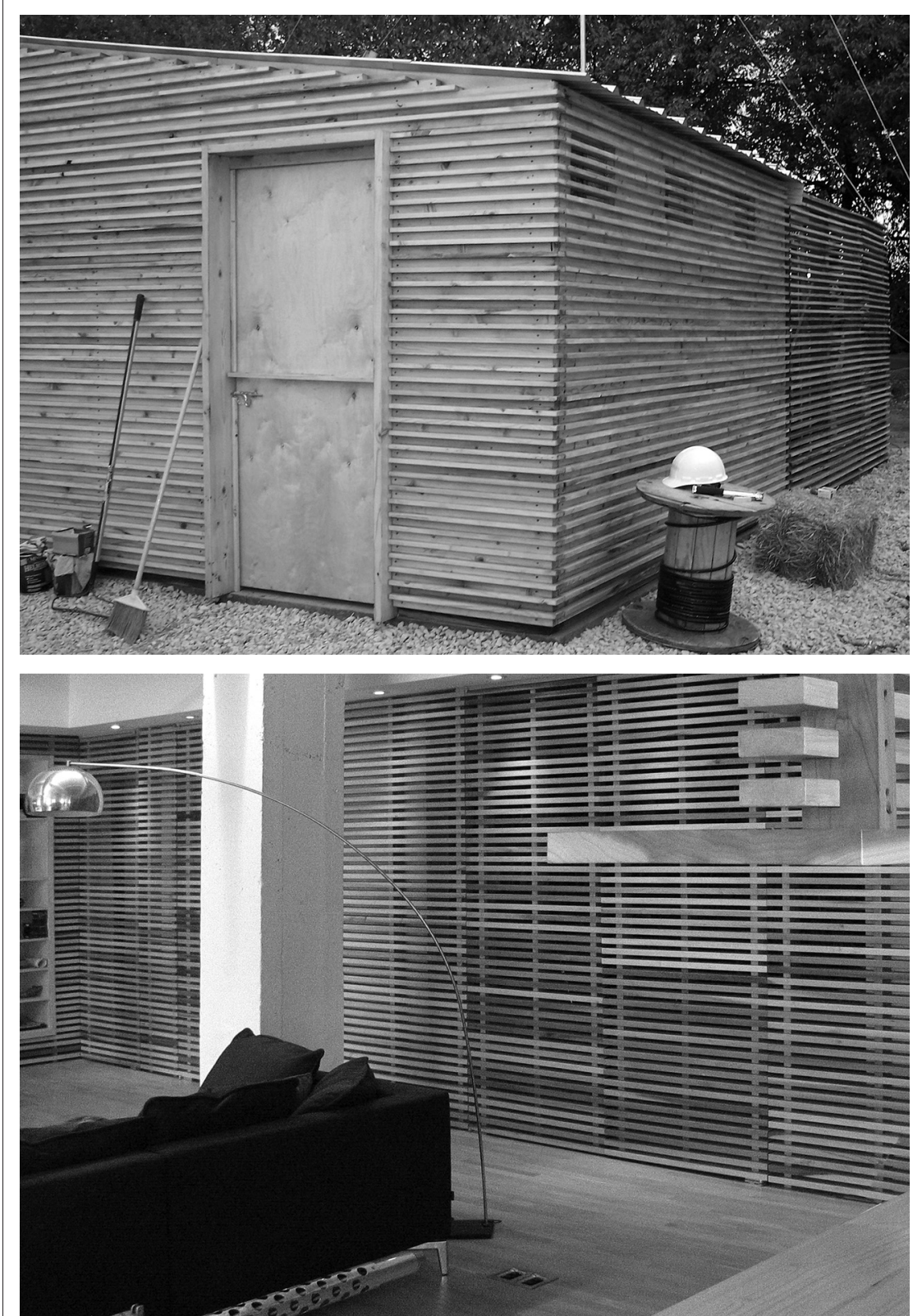

Top, chicken coop constructed by students as part of a reality television show Bottom, New York City loft designed by Larry Bowne ever seem an appropriate application of my training and experience? Porcine clichés snort their way into my mind: silk from sows' ears, pearls before swine...

I altered my trajectory, and when I began to teach I decided that for a time I would try architecture withou clients. The history of architecture is a history of patronage, and I thought I would try to make a body of work in which the autocracy of resources might be less hegemonic.

PR: How do you feel high design and innovative technologies, usually reserved for the upper echelon, can benefit architecture, especially architecturaleducation and community-based design?

LB: One of the most exciting things about the work we are looking at here is that it is community-based-the people are doing it for themselves. The architect's role, if indeed the architect has any role at all, might be as goad or as guide. But Ayn Rand-notions of individual genius, in which, the Great Man brings his precious gifts down from the peak to be shared by the little people, have no place here.

As you note, digital communication can be remarkably fluid and open (though by no means universally so; from lawsuits against music downloaders to Google censorship in China, the free flow of information is often not free and not flowing). Digital fabrication may be even more fluid. We can imagine a planet in which architects like Laurie Baker can impact not merely a village but an entire culture of building. People can assemble the means and materials they need to transform their own communities. The architect then becomes a vital participant in the nascent ways of the community, not a purveyor of elite or erudite knowledge. The architect becomes a hands-on, practical, consensus builder. Architects by training have a wonderful capacity to synthesize discrete facts, from widths of waste lines to passive heating techniques, but rarely do we employ these skills unless they are on an ad-hoc or one-off basis. To look at it a different way, a client traditionally comes to an architect with a problem or situation concerning his property, and the architect proposes a unique solution to the presented conditions. Every problem requires a discrete and custom response; the solution always requires expertise. In an alternate model, the community and the architect seek each other out, they identify ways in which the community might improve their lot, and they assemble the means and materials necessary for the folks involved to solve their own problems. In this manner, an architecture for what you call "the other 99\%" is not really an architecture at all, if by architecture we mean the inspired design of some protean being.

The trouble is getting started. How does a school, particularly one without 
an established design/build program, initiate the kind of work you are trying to do in New Orleans?

PR: Your question has two answers, I think. First, there has to be someone at that school who cares to do it. That's it. The majority of design/build programs, nonprofit, and for-profit, for that matter, exist, not out of policy decisions, but because one passionate person on a mission made a decision to make it happen. Although that person also has to have a certain knowledge or expertise such as how to identify need, through the media or word of mouth, or how to implement a construction project, he has to want to do it. The birth of all of my projects, through Project Locus, has come down to one thing: making a phone call, which requires both knowledge and desire. I recently told a group of my students that I could teach them how to fix a car, but unless they wanted to be mechanics, there was no use in it. I recall several years ago Sam Mockbee, during and open interview for the directorship of SCI-Arc, was asked if he would be able to replicate the work of the Rural Studio in Los Angeles, and if his work wasn't too regional to apply to the urban context. He remarked that he could make ten phone calls and have every student working by the morning. Also, he asked if it was more important what the work looked like, or that it was being done. Our training as architects and designers will account for aesthetics (beauty). What I learned and our response to it are not regional. This kind of work can and needs to be done everywhere. People simply have to want to do it.

\section{LB: And the second part?}

PR: There is still the question of how. This particularly applies to those institutions without equipment, space, or policy in place to operate a design/build program in the traditional sense. Most university architecture programs either have no established community-based design/build program or operate design/ build projects in an ad-hoc manner. Contributing factors are lack of variability in project scope undertaken by current program models, whose large scale, full-immersion approach and high liability are a major deterrent to budding programs. The educational benefits of traditional models are questionable as construction methods become increasingly conventional to better control deadlines and budgets, reducing students' exposure to innovative materials and systems.

LB: So what's the solution?

PR: I think the answer to this problem is technology, at the level of process. Rapid prototyping and prefabrication allow for projects to be designed and constructed in a central, on-campus location, minimizing site work and liability while maximizing student learning. In this new model, students design and build parts and systems,
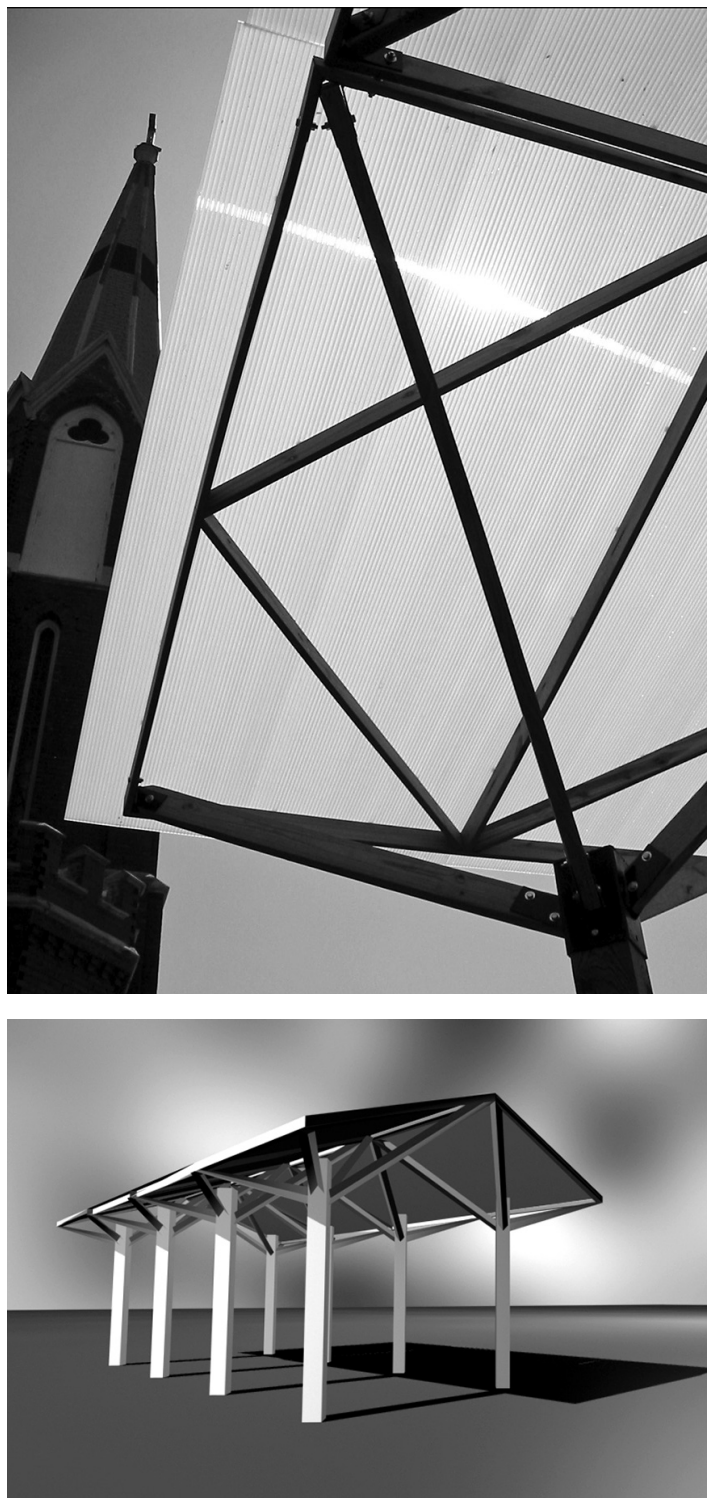

Butler Trees Modular Shelter-Tomas Martinek, Alejandra Soto, Judd Webb, and Eric Wittman, B.Arch. 2006

Shading devices placed on church grounds in Blaine, Kansas. The tree-inspired elements were constructed from wood, steel, and a polycarbonate panels. 
manageable in terms of size and scope which are later assembled, either as a single studio project or in cooperation with other studios, departments, uni versities, nonprofits, or private practice. This type of work is especially applicable to our work in New Orleans, where the infrastructure is questionable in terms of housing volunteers and supporting an on-site shop, requiring most of the work to be done off-site in modular format. The result is the creation of a highly mobile and replicable design process which supports community development while maintaining students normal way of life and promoting a mechanism for design/build to be more easily adopted by any institution with minimal overhead and liability. This new model pushes the boundaries of architectural practice through innovative technologies and collaborations leading to new, marketable products, and systems that may create a sustainable base for future projects.

LB: Does a person or organization have to have an institutional affiliation, either with a university or non-profit, in order to contribute to community building?

PR: The simple answer is no. Of course, not. There are millions, if not billions of people who contribute to the positive growth of their communities around the world, every day, in big ways and in very small ways. Although it's true that, in this country at least, it facilitates the funding process to have 501(c)(3) status, professional affiliations and partnerships (and that most good work is accomplished through com munication and organization with others), there are so many examples of people throughout history affecting great change all by themselves. I think the point to be made here is that there is just not enough work being done by members of the architecture profession specifically, in this regard. The fact that architecture is fee-based may be to blame, although despite this, the profession has seen a recent surge in service and pro bono work. Which leads me to my next question: based on your response to the 1\% question, wouldn't you then consider yourself a humanitarian, in the strictest sense of the word?

LB: I don't know. Your question makes me think about a whole range of life choices I have made. In short, I don't think my role is to provide succor to another soul. But I would say that am a humanist, in the broadest sense of that word. I think that through the awareness of ourselves and our place in the world, we can know thing beyond ourselves and our place in the world. The betterment of the self is ultimately the knowing of eternity "Know thyself," commanded the oracle of Delphi, and nearly all faiths contain this nugget of wisdom.

To have genuine self-awareness, we have to come to know what we do and how we do it, and maybe even start to see why. We have to come to know how we might contribute to the patterns of being as we see them. Every man can leave the world a better place, and, if we know our gifts, and know how to apply them, we can work towards a more complete contribution.

Otherwise, why would we have had this time on the planet? What are we here for, except to know ourselves and know our place in the order of things? We have six or seven or so decades, and we have to do all we can to see that we use that time to create more love and beauty than we found when we arrived.

PR: Which do you think is the case: that, through this conversation, we are trying to get at what the future of design/build might be; or, that we are discovering that the future of architec ture is humanitarian design?

LB: I think we are discussing ways in which design/build might serve larger social and political needs. Students who are largely young, have gifts, and we allocate time to their musings and idlings and wanderings; we forgive them transgressions that we would not tolerate in a more mature adult. Students have a passion, optimism and a hope for the future that, in the last several decades, architecture schools have been remiss in accessing and directing.

As you know, our curriculum has no established design/build program. I did a project in the fall, as part of a reality television show, which had the support of the college. We designed and built a chicken coop for a poor family who had lost everything in a domestic tragedy. During the process, I was astounded at the energy and enthusiasm of students. They want to help people; they want to make a contribution.

Design/build, in a local context and at a manageable scale, offers the possibility of channeling student energies towards the real contribution of artifacts in the world, objects and pieces and places that benefit people.

So I suppose my answer to your question is that we are discussing the future of design/build as a means for the realization of an architecture which brings beauty, and grace to the everyday lives of common citizens. We are not discussing one or the other, or even one versus the other; we are discussing how one might become the other.

Patrick Rhodes and Larry Bowne will be working together this summer with Kansas State University students to rebuild the House of Dance and Feathers Museum for Mardi Gras Indians and Community Center in the Lower Ninth Ward of New Orleans. 